\title{
THE STUDY OF INDONESIA'S READINESS TO COPE WITH DEMOGRAPHIC BONUS: A REVIEW OF POPULATION LAW
}

\author{
Edie Toet Hendratno
}

Faculty of Law

Universitas Pancasila

(edie_toet@yahoo.com)

\author{
Rachma Fitriati \\ Faculty of Administrative Science \\ Universitas Indonesia \\ (rachmafi@yahoo.com)
}

\begin{abstract}
The shift from a population mapping to investigate the population bonus on demographic aspect enhances the economic value this study might contribute for. Indonesian population as the fourth largest number requires some policies to cope with the millennium challenges. Improving nationwide database maintains government on-going strategy to manage its population that is expected to serve all stakeholders for any quest towards economic development. The study uses mixed method with the explanatory sequential strategy. The qualitative approach is used, using social network analysis, supported by desk study, in-depth interview, focus group discussion, and literature studies. This study attempts to provide for improvement to the extant regulations on identity card, mostly electronic-KTP. Demographic bonus is an interesting topic given that the younger the population, the higher the employment demand rate will be. Having systematic database bank and access is expected to alleviate the challenge on high population growth rate in Indonesia. Besides, recommendations are addressed to the policy maker (the Government), mostly on the review or amendment of the extant regulations that might not in line with the database systematic improvements. The study is a primary thesis from a review of population law, using multidisciplinary approach, i.e. population economics (demography), legal study, and public policy that can be used as a testing basis to answer further demographic bonus from an exploration of other scientific inquiries.
\end{abstract}

Keywords: demographic economy, demographic bonus, population administration law, e-ID, social network analysis

\section{INTRODUCTION}

Seen from the human resources demographic point of view, Indonesia has the fourth largest population in the world, after China, USA, India and Russia. Based on the data from the Directorate General of Population and Civil Registry, Ministry of Home Affairs at the second half of 2014 it is amounted to $255,153,932$ people. Moreover, Indonesia is currently in a transition period of the productive age population structure, expecting to get a bonus of demography (demographic dividend) in the period of 2020-
2030. This demographic dividend provides huge benefit potential in terms of development and economy, i.e. when the composition of productive age population (15-64 years) reaches a maximum point, compared to non-productive age ( $0-14$ years old and over 65 years).

This demographic dividend can provide economic benefits, because the total savings of the productive population will be greater so as to spur investment and economic growth. This fact indicates the increasing importance of employ- 
ment in order to take advantage of population number of the productive age.

Looking at the connection between demography and economy, then Kelley and Schmidt (2008) and van Praag (1988) propose a science called demographic economy as an economic analysis by making demography and population as the main object. The science also means analyzing the number of growth, and population distribution. Lee (2008), galor (2008), Johnson and Lee (1987), Kelley (1988), Brander (1994), Kremer (1993), Dasgupta (1995) have intermittently argued on population growth that is generally expressed as population change occurring any time, and can be calculated as a change in the number of individuals in a population using "per time unit " for measurement.

According to Bloom, Canning, and Sevilla (2003), there are four (4) mechanisms by which the demographic bonus can be said to give benefit, namely 1) when the increasing supply of labor can be absorbed and productive; 2) when the increasing savings also increase the capital stock of a country; 3) when the decreasing fertility rates result in healthy women and lesser domestic economic pressures; 4) when the growth of domestic demand increases due to the increase in GDP per capita and the decline in dependency ratio. The condition is also known as Window of Opportunity where every country accelerates its economy by optimizing the entire sectors because of the abundance of production factors of labor. The purpose of acceleration is not as important as the efforts to increase the per capita income in order to achieve prosperity.

Based on the aforementioned background, this article aims to answer the challenge of demographic dividend in Indonesia by reviewing the policy of electronic identity card (known in Indonesia as e-KTP or KTP-el), through a mapping of population policy as follows: First, The Government Regulation No. 37 of 2007 on the implementation of Law No. 23 Year 2006 concerning Population Administration. Second, Presidential Decree No. 25 of 2008 on the Requirements and Procedures for Civic Registrations and Civil Records. Third, The Presidential Decree No. 26 of 2009 on the Implementa- tion of National NIK-based KTP. Fourth, Presidential Decree No. 35 of 2010 on the Amendment of Presidential Decree No. 26 of 2009 on the National Implementation of KTP Based on the Civic Registration Number (NIK). Fifth, Presidential Decree No. 126 of 2012 on Third Amendment to Presidential Decree No.26 of 2009 on the Implementation of NIK-based KTP Nationwide.

By mapping these policies, as a civic database, e-KTP should be accurate and harmonized with the regulations. National policy should also be taken strategically; so that the challenges of demographic bonus in Indonesia can be a 'blessing', a boon for the development in Indonesia through improved and refinement of population policies in Indonesia.

\section{LITERATURE REVIEW}

The term of population growth commonly refers to the growth of the human, and is often used informally to designate demographic development. Population can change through 3 (three) processes: fertility, mortality, and migration. Fertility involves the number of children. Demographics mostly studies mortality by using life table, statistical device that provides information about the condition of death (especially life expectancy) in the population ${ }^{1}$.

The study conducted by Balan (2015) reveals the relationship between the total fertility rate (fertility) and GDP per capita, referring to the paradox of demographic economy in developed countries in the world. In general, the demographic-economic paradox is understood when a country with high GDP tends to have low birth rate. In other words, high fertility is expected to reduce economic growth (Barro 2003). However, Birg (2001) argues that demographic-economic paradox refers to the proposition that the value of a country's GDP will not always predispose a person to have a child.

Another theory, as revealed by Malthus (2000), states that fertility can lead to poverty due to the extant condition of natural resources,

\footnotetext{
${ }^{1}$ http://www.cdc.gov/nchs/products/life tables.htm. accessed on 8 November 2015
} 
which are presented in the "population trap". However, the theoretical model built by Galor and Weil 1996, 1999, 2000; de la Croix and Doepke 2003; Doepke 2004; Galor 2005 assumes that the reduction in the number of family members will increase personal savings and make the household focus on children they have. Thus, parents as productive labor force will be more productive and boost economic growth (Luci and Thevenon 2010).

Concerning the effect of population growth and fertility on economic growth, Brander and Dowrick (1994) find that a high birth rate might cause a decrease in economic growth derived from the effect of investment and capital dilution. Mishra et al. (2006) investigate the relationship between the rate of female labor force participation and the total fertility rate for the $\mathrm{G} 7$ countries over the period 1960-2004. By using a panel of co-integration and Granger causality analysis, the study found that the variables are co-integrated and Granger causality relation between total fertility rate and the rate of female labor force participation is detected.

Moreover, Li and Zhang (2007) investigate the impact of birth rate on the economic growth, using panel data set of 28 provinces in China. By using a common method of moment estimator, the empirical findings show that birth rate has a negative effect on economic growth. This study supports Malthus' ideas on birth control policy. In addition Cătăneţ and Cătăneţ (2008) examine the determinant factors of economic growth in more than 150 countries. Their findings suggest that economic growth is negatively correlated with fertility and population growth.

Therefore to encounter population and development issues in developing countries, the more serious challenge faced by scientists and policy actors is to achieve a better understanding of the complex process of demographic transition and to obtain clearer information base for policy making (Teitelbaum, 1975). As a consequence, according to Asshiddiqie (2011), the state has an interest to know systematically and accurately its own people, enabling to determine the appropriate government policies. This study aims to review the policy of the resident identity in the form of electronic Identity Card (KTP-el), which is a form of digitalizing resident's personal identity through electronic identification (e-ID) or a smart card ID, first introduced in 1970 by Al-Khouri and Bal, 2007.

\section{THE NATIONAL IDENTITY SYSTEM}

According to Castro (2011) and Soemartono (2013), since long time ago, a number of European countries already implemented an accurate and integrated civic database system. The National Identity System is manifested in the form of e-ID, such as in Belgium in 2004, Finland in 1999, Estonia in 2002, and Italy in 2002. The implementation of e-ID authentication in European countries is different from one another: in Belgium through the identification of certificate, existing in e-ID; whereas in Portugal and Spain using public key infrastructure systems in e-ID authentication.

The Unitary State of the Republic of Indonesia, based on Pancasila (the state philosophy) and the 1945 Constitution of the Republic of Indonesia, is essentially obliged to provide protection and recognize the determination of personal status and the legal status of each civic event and vital event experienced by people inside and/or outside its territory. The Law on Population Administration No. 23 of 2006 lists the settings and the establishment of a system that reflects a reform in the field of population administration.

One crucial issue is the regulation concerning the use of Civic Registration Number (NIK). NIK is the identity of Indonesia's population and is the access key to data verification and validation of one's identity in order to support public services in the field of administration. As a system, population administration must be executed as part of state administration. From the interests of the population, population administration fulfills administrative rights without discrimination. In that term, some efforts are needed to establish: (1) a neat population database, including the establishment of accurate population database at the districts/cities, and provinces, nationally online. (2) a neat NIK publication. and (3) a neat civil documents. In addition, the strategy 
undertaken in order to realize orderly population administration is through updating the population database, improving the quality of the database by using the online SIAK, accelerating and reinforcing regulation in the regions through Regional Regulation (Perda) on population administration and followed by enforcing law for administrative violations, at the initial application of the nationally NIK-based KTP.

While Indonesia uses an e-KTP or Electronic Identity Card. e-KTP is a document of citizen identity proof, stored in electronic recording. Law No. 23 Year 2006 concerning the Population administration as an elaboration of the mandate in Article 26 paragraph (3) of the Constitution of the Republic of Indonesia Year 1945 aims to achieve an orderly population administration through the establishment of national civic database as well as the validity and legality of the issued citizen document.

Therefore, based on the aforementioned problem, the research question in this study are:

1. How is the review of regulation on population identity (in the form of electronic Identity Card) in Indonesia?

2. What kind of policy improvements should be done by the Government of Indonesia in addressing the challenges of demographic bonus?

\section{METHODS}

The study uses multidisciplinary approach, combining studies of demography, public policy and legal study on population. Referring to the objectives of the mixed method study using explanatory sequential strategy (Creswell, 2003 and 2013), the priority is more on quantitative approach, supported by qualitative data.

The qualitative approach is used, using social network analysis, supported by desk study, in-depth interview, focus group discussion, and literature studies (Guba and Lincoln, 1994; Denzin and Lincoln, 2011). The in-depth interviews and focus group discussions had been done by Meleng, et al. (2015) which we used as secondary data. By Meleng, et al. (2015), those premier data collection was coded in order to distinguish overall themes, followed by a more in depth, interpretive code in which more specific trends and patterns can be interpreted (Hay, 2010; Can, Özyer, and Polat, 2014).

Social Network Analysis (SNA) is used since: analyzing policy review using quantitave approach (by Node XL software tool) is required to hinder common sense. Second, SNA is rarely used in population economic study, thus can be considered as novelty of this study.

Social Network Analysis (SNA) has become a new trend in recent years. SNA is a method to examine the structure of social relations within a group to uncover the formal relationships between the actors (Valdis, 2014; Ulrike, 2001).

SNA is a sociological paradigm to analyze the pattern of social relation structure (Wellman and Berkowitz, 1988; Scott, 1991; Hanneman, 2005; Fitriati 2014), which focuses on relationships among social entities. It is used widely in the social and behavioral sciences, as well as in economics, marketing, and industrial engineering (Wasserman and Faust, 1994). SNA is used in this study to analyze social network, to study the structure of formal relation among actors in population policy.

SNA shall identify, map, and eventually recommend a knowledge transformation in a social network (Ulrike, 2001; Müller-Prothmann, 2006), including in the population policy network as a system of national identity to address the challenges of demographic bonus.

This method is used to analyze the network cohesion, density, and dimensions, and individually analyze each actor who is important and has influence in social networks (Wasserman and Faust, 1994). The focus of SNA is to study the involved key-player actor (nodes) and how the relationship occurs (relationships within and between networks), to whom the nodes are connected, how strong the relationship exists, how does relationship happen, is it one-way or twoways, how is the relationship facilitated, through which various regulations does the relationship happen, up to how to apply the relationship (Fitriati, 2014). SNA analysis results provide valuable information in describing the relation- 
ship between the actor who plays the dominant role in social interaction.

The use of SNA method in the analysis of a network that has the basic measurement principle of mathematical calculations is significantly understood to determine the connectivity patterns in the analyzed network. The basic measurements include: network size, degree, density, reach-ability, connectivity, distance, and the flow of information.

The basic level analysis in SNA is a dyad, i.e. two nodes and the relationships between them. However, the focus of the analysis can be directed at the network environment of individual node (ego-networks) or at the structure of the entire networks, depending on the interest of researcher (Christopoulos, 2006). This analysis is usually based on quantitative measures; in individual level it centers on the actors in the network, while in structural level on the network density.

In the measurement, the stages of calculating by Node XL software tool are as follow:

1. Collecting all regulations related to e-KTP as the data source of SNA. The policies related to e-KTP are: Law No. 24 of 2013 on the Amendment of Law No. 23 of 2006 concerning Population administration

Furthermore, there are also several Presidential Decrees used as reference in order to implement the e-KTP policy.

While the regulations as the Implementation Guidelines that have been issued by the Minister of Home Affairs and made as references are among others; Minister of Home Affairs Regulation No. 9 of 2011 concerning Guidelines for the Issuance of National NIKbased KTP.

The entire regulations mentioned above are then used as references for searching actors related to the implementation of e-KTP policy in Indonesia.

2. Listing nodes as subject or object in legal relations in "vertices" worksheet.

3. Relating between nodes as subject and object through the predicate in "edges" worksheet.
4. Analyzing process of SNA software to display its metric analysis and its visualization (see Figure 1).

5. Getting the result of metric analysis and SNA visualization (see Figure 2).

The visualization of social network aims to portray the relations between nodes. Microsoft NodeXL has automatically calculating several values of centrality, betweenness centrality, closeness centrality and eigenvector, where the calculation of both centralities has been explained previously.

Degree centrality is a measure that shows the ability of (amount of) node in relating actors or other attributes (see Figure 3).

Degree centrality consists of two types:

a. In degree; a measure in degree centrality, showing that an actor has become the most accessed by other actors, or the actor who plays a role as the object. Node with the highest in degree value has an important position as an access center of other nodes; in other words other nodes try to establish a contact or relation with this node.

b. Out degree; a measure in degree centrality, showing that an actor most accessing other actors, or the actor most frequently play the role of subject in SNA networks. The node with the highest our degree value indicates an actor who has crucial position in the networks.

Degree Centrality will calculate the weight of the i-th node (notated $C_{D}(i)$ ), based on the number of edges formed between node $\mathrm{i}$ and other nodes. The simple formula for calculating the weight of a node is the following normalization form (Adamic, 2008):

$$
C_{D}(i)=\frac{d(i)}{n-1}
$$

Calculating the degree centrality of A-th node has the value of $C_{D}(A)=2 /(4-1)$, i.e. the number of edge(s) formed on node $\mathrm{A}$ with other nodes connected to node $\mathrm{B}$ and node $\mathrm{D}$ divided by the number of nodes in the graph with the total of 4 subtracted by 1 . The value resulted 
from the calculation is $C_{D(A)}=2 / 3=0,667$. While for node $B$ the value is $C_{D(B)}=3 / 3=1$.

Betweenness centrality is a measure that shows how much an actor can facilitate communication with other actors in a network (see Figure 4).

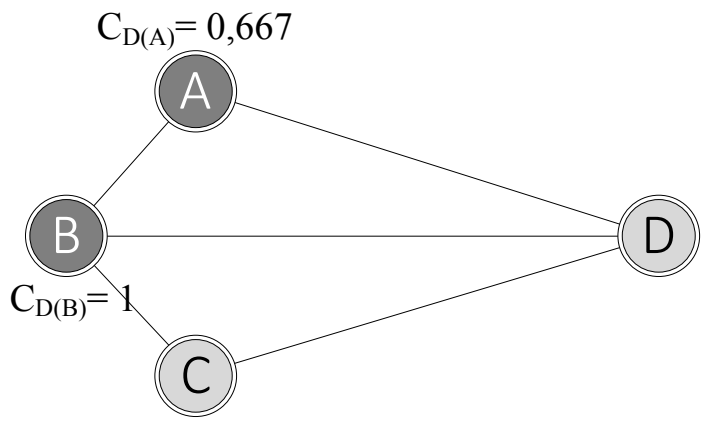

Figure 3. An Example of Degree Centality Measurement

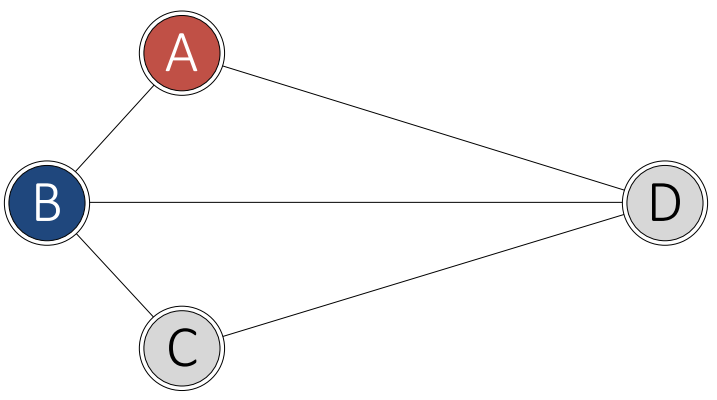

Figure 4. An Example of Betweenness Centrality Measurement

Mathematically, this measure calculates the weight of each node based on how many the node $\mathrm{i}$ is traversed by two other nodes in the graph based on its shortest path. The calculation of the weight for each node could use the following formula (Adamic, 2008).

$$
C^{\prime}{ }_{B}(i)=\frac{2 \sum_{j<k} \frac{p_{j k}(i)}{p_{j k}}}{(n-1)(n-2)}
$$

$P_{j k}(i)$ is the number of the shortest link between node $\mathrm{j}$ and $\mathrm{k}$ passing node $\mathrm{i}$, while $\mathrm{Pjk}$ is the number of the shortest link between node $j$ and $\mathrm{k}$.

Based on Table 1, the calculation may measure the value $\mathrm{C}_{\mathrm{B}(\mathrm{A})}=\mathrm{C}_{\mathrm{B}(\mathrm{C})}=0$, while $\mathrm{C}_{\mathrm{B}(\mathrm{B})}=\mathrm{C}_{\mathrm{B}(\mathrm{D})}$ $=(2 * 0.5) /(4-1) *(4-2)=1 / 6$.

Table 1. Explanation of Betweenness Centrality Measurement

\begin{tabular}{lccc}
\hline & $\mathbf{P}_{\mathbf{j k}}(\mathbf{i})$ & $\mathbf{P j k}$ & $\mathbf{P}_{\mathbf{j k}}(\mathbf{i}) / \mathbf{P j k}$ \\
\hline Node A & $\mathrm{BAD}(1)$ & $2(\mathrm{BAD}, \mathrm{DAB})$ & $1 / 2$ \\
Node B & - & - & $?=0$ \\
Node C & $\mathrm{BCD}(1)$ & $2(\mathrm{BCD}, \mathrm{DCB})$ & $1 / 2$ \\
Node D & - & - & $?=0$ \\
\hline
\end{tabular}

Closeness centrality is a measure that shows the average distance between a node to all other nodes in a network (see Figure 5).

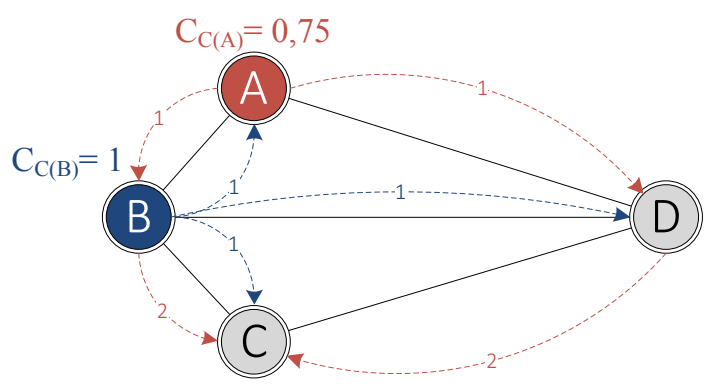

Figure 5. An Example of Closeness Centrality Measurement

The higher the node proximity value, the easier the node disseminates information in the network. Conversely, the lower the node proximity value, the farther the distance between the actor with other actors; hence the dissemination of information from informants is quite difficult.

Mathematically it is the closeness centrality which will calculate the weight of centrality of a node based on the number of shortest distance between nodes $i$ with other nodes. To calculate the weight of closeness centrality of each node, the formula used as normalization is as follows (Adamic, 2008):

$$
C_{c}(i)=\frac{n-1}{\sum_{j=1}^{n} d(i, j)}
$$

Calculating closeness centrality of A-th node has the value of $C_{C(A)}=(4-1) /(1+2+1)=0.75$. The formula consists of: $n$, that is the number of nodes connected in the network, the value of which is 4 ; $\mathrm{i}$, that is the number of node A connected to the closest node $\mathrm{B}$ only through 1 connection ( 1 edge); and $\mathrm{j}$, that is the number of node $\mathrm{A}$ to the closest node $\mathrm{C}$ through 2 connections, i.e. node $\mathrm{A}$ to node $\mathrm{B}$ then node $\mathrm{B}$ to node C. It can also go through other connections, from node $\mathrm{A}$ to node $\mathrm{D}$ then from node $\mathrm{D}$ to node $\mathrm{C}$. 
With similar calculation the value obtained is $\mathrm{C}_{\mathrm{C}(\mathrm{B})}=3 /(1+1+1)=1$.

Eigenvector centrality is the type of measurement to find the most central actor in the SNA network (see Figure 6).

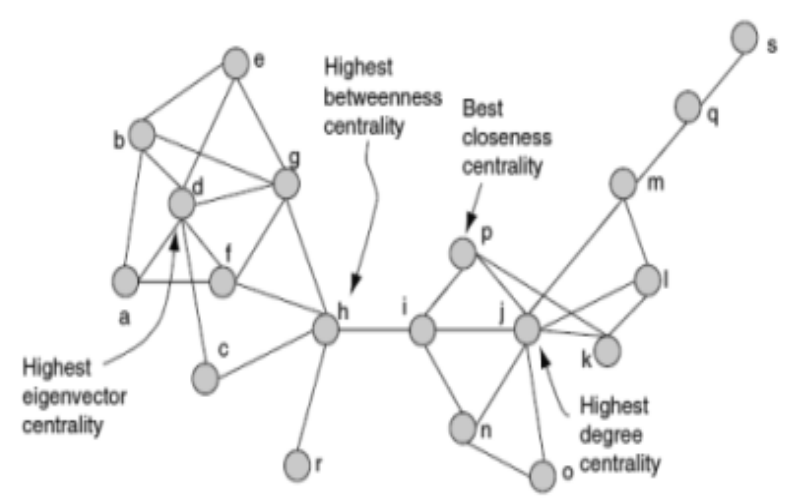

Figure 6. Example of eigenvector centrality

Eigenvector centrality is the type of measurement to find the most central actor in the SNA network. Through eigenvector centrality, the general distance between actors in a network pattern will be known. The actor with the highest value of eigenvector centrality becomes an actor with the most important role. The crucial role is obtained, since through the measuring of eigenvector centrality, the most popular actors with most relationships with other actors in the network will be known. Eigenvector centrality in general will produce a list of actors with the highest value almost equal to the degree centrality (Marsden, 2002).

This similarity is due to the fact that eigenvector centrality is a recursive version of the degree centrality. This similarity is also evidenced by the result of eigenvector centrality calculation within the legislation and policy actors of e-KTP implementation

\section{RESULTS AND DISCUSSION}

To obtain an integrated population system in Indonesia, Law No. 24 of 2013 Article 82 mandates the Minister of Internal Affairs of the Republic of Indonesia to perform the management of population administration through the development of Population Administration
Information System (SIAK). SIAK implementation aims to achieve: (1) Orderly Population Database, (2) Orderly NIK Publishing, and 3) Orderly Population Documents.

SIAK is done by building a Database System for Population and accurate demographic document. The registration-based SIAK documentation is conducted by the Office of Population and Civil Registration at the district/municipal, provincial, as well as the Central levels. Furthermore, this demographic database must be connected on-line with the ones of the district/municipal and the provincial governments as well as the central government, and vice versa.

In line with the objectives of the Population Administration, the construction and development of SIAK is aimed at establishing the national commitment in order to create a single identifier system, in the form of Personal Identification Number (NIK), for the entire population of Indonesia. This means that the population data can be integrated with data from the Population Registry services and civil registration services.

It is reinforced by the interviews with the Director of the Population Administration Information Management of the Ministry of the Internal Affairs, showing that in order to obtain valid and updated data, SIAK is required to facilitate services of population registry and civil record. This system will produce dynamic and updated national population data through daily services of registration-based population and civil record conducted by the Office of Population and Civil Registry at the district/city as a data input for SIAK.

In the application of KTP-el, in fact, the Ministry of Internal Affairs has sought acceleration through several policy strategies: First, it established a Steering Team of Personal Identification Number Publishing, and Nationwide NIK-based Identity Card Implementation. Second, in 2010, it updated the demographic data in all districts/cities using funds from the State Budget, and issued NIK in 329 districts/ cities. Third, in 2011 it published Personal Identification Number (NIK) in 168 districts/cities 
and implementing KTP-el in 197 districts/cities, and appointed the Expert Team of the Directorate General of Population and Civil Registration of the Ministry of Internal Affairs. Fourth, in 2012, it established the Implementing Team of Electronic Identity Card at the Directorate General of Population and Civil Registration. Fifth, It issued Letters/Circular Letters addressed to Governors and Regents/Mayors throughout Indonesia, so that the Office of Population and Civil Registration, as the Regional apparatus responsible for the Population Administration, immediately implements the policy of e-KTP.

Nevertheless in its implementation, there still many compelled residents who have not registered themselves for e-KTP. Teitelbaum's argument is still relevant with the present condition: only few policy-actors understand the urgency of population problems and use demographic information as the basis for policy-making. Here the urgency for nationally managed, effective, and accurate population-administration emerges.

The SNA study, analyzing the formal relation structure among actors in population policy, aims to build a system of national identity that helps strengthen national competitiveness. The focus of SNA is to learn the stakeholders (actors) involved and how the relationship occurs on the E-KTP Policies (intra- and internetworks relationships) within the framework of competitiveness. The result shows: the stakeholders (actors) already existing in a number of existing regulations/Laws are 87 actors (Table 2) and 75 relations/links (Table 3 ) contained in the regulations of the National e-KTP. This mapping result shows that the population plays the most significant role as facilitator, bridging the communication in the regulation of the National eKTP.

The visualization of SNA aims to describe the relation between actors interacting in policies related to the implementation of e-KTP (Table 4). In the visualization we can perceive the actors frequently accessed and accessing other actors, some significant actors among other actors in the policies related to the implementation of e-KTP (Figure 5).
The result of data processing with Social Network Analysis illustrates that the population became the main actors in the policies related to the implementation of e-KTP. Another figure shows that other significant actors are the Executing Institutions, Office of Civil Registry (Dukcapil), Officers, Head of administrative village, Resident Aliens, and the Minister of Home Affairs. This means that the policies related to the implementation of e-KTP are dominated by networks originating and leading to the actors.

In the regulation of e-KTP, residents are supposed to be the main actor, given that population is the actor imposed by these policies. Furthermore the Executing Institutions, Dukcapil, and officers also rightly become the dominant actors in the regulation of these policies, since they are obliged to serve the population for the administration of the e-KTP on the field. In addition to the four actors, there are other actors, frequently mentioned in e-KTP policies such as the head of administrative village, Resident Aliens, and the Minister of Home Affairs.

\section{Matrix Analysis and its Visualization}

For the degree centrality, in the SNA analysis there are three measurements that can give information concerning the role of actors in the SNA networks, as follows:

\section{(1) Degree centrality}

\section{In-Degree}

In the policies related to the implementation of e-KTP, there are some actors who have a higher in-degree value. The result of data processing with Social Network Analysis shows 87 actors with the highest in-degree value in the eKTP implementation policies.

By using Degree Centality Measurement like Figure 3, Table 5 and Figure 7 are obtained. The tables and figures The table and Figure explain the visualization of in-degree SNA that indicates the highest in-degree value is the population, which is quite adrift far from other actors. This suggests that the population is an actor most frequently accessed by other actors in the policies 
related to the implementation of e-KTP. In other words, residents in relations with other actors often play a role as the object in the e-KTP policies.

\section{Out-Degree}

In the policies related to the implementation of e-KTP, there are some actors who have a higher out-degree value. By using Degree Centality Measurement like Figure 3, Table 6 and Figure 8 are obtained. The table and figure explain the out-degree visualization of SNA which shows the highest out-degree value is the Minister of Home Affairs. This value is derived from the many numbers of connections accessed by the Minister of Home Affairs in the SNA network. Minister of Home Affairs is the actor that plays an important role holding the authority and ability to access other actors. The ability to access other actors was obtained from this authority as being a Minister of Home Affairs and holding the policies related to the implementation of e-KTP.

Through the authority, the Minister of Home Affairs has a very central position in terms of an actor most accessing other actors. Directional arrows originating from the Minister of Home Affairs shows that the Minister of Home Affairs accessed other actors or acted as subjects in a relationship with other actors. The position as the actor most widely accessing other actors make the Minister the most important actor in the policies related to the implementation of eKTP.

The actor who has the next significant role as the subject is the Governor and Regent/Mayor. As regional leaders, both have significant authorities in relation to the implementation of eKTP policy. The significant authority can be known through the Government Regulation No. 37 of 2007 on the implementation of Law No. 23/2006 concerning Population administration.

\section{(2) Betweenness Centrality}

Betweenness centrality becomes a tool to determine how well an actor becomes a facilitator of other actors in a network. The actor/node who has the highest value of betweenness cen- trality is an actor who has the highest capacity to facilitate the interaction between nodes so that they can be interconnected. In addition, if the actors with the highest betweenness centrality value are eliminated, it may cause disconnection in the network. The result of data processing on the regulations and policies that are used to using Social Network Analysis in the implementation of e-KTP shows that the population becomes the actor/node with the highest betweenness centrality value.

By using Betweenness Centrality Measurement like Figure 4, Table 7 and Figure 9 are obtained. This high value makes the population a facilitator, capable to bridge the communication in the implementation of e-KTP.

\section{Betwenness Anomaly}

Betweenness anomaly is the type of measurement to determine how significant is the role of an actor/node who becomes a liaison between other nodes so that the inter-nodes becomes the outer link in the connectivity. In other words, betweenness anomaly becomes a metric tool to determine the outer actor facilitating other actors in the network. the actor/node with the highest value of betweenness anomaly is an actor with the lowest or small capacity to facilitate interaction between nodes to be interconnected.

The result shows that in fact the ownership of e-KTP has a lack of connectivity with a birth certificate policy, whereas birth certificate is the basis of the right to identity of every citizen. A birth certificate is an absolute requirement for a child to go to school, make passports and claim other rights to identity.

Seen from the table of betweennes anomaly, the regulation of e-KTP is not in line with the regulation of identity rights. Parents, doctors, midwives, paramedics, birth attendants, family, chieftain/customs, police, power, religious courts, district courts and civil registration are surprisingly actors who have the least or small capacity to facilitate interaction between nodes so that they can be interconnected.

\section{Closeness Centrality}


Closeness centrality is used to measure the average distance between an actor/node with other actors/nodes in a network. Closeness centrality is also used to measure how much information can be transmitted from one node to other nodes. The size of closeness centrality can be a picture to measure the proximity of an actor with other actors. The closer the relationship of an actor with other actors, the easier he gets information from other actors. The higher the proximity value is, the easier an actor disseminate information to other actors. The lower the proximity value is, the farther the distance of an actor with other actors is. The table shows the closeness centrality value resulting from the actors related to the implementation of e-KTP.

From the result it can be seen that Population is the actor with the highest value of closeness centrality. It is further clarified by the following figure, showing the proximity owned by Population with other connected actors within the regulation of e-KTP implementation.

By using Closeness Centrality Measurement like Figure 5, Table 8 and Figure 10 are obtained. The table and figure show that the population has a relationship with many other actors such as the Executing Institutions, officers, Dukcapil, the head of administrative villages, village chief and other actors. By using measurements of nodeXL, the population's closeness centrality value of 0.008 shows that they have close relationships with other actors, thus it is quite easy for them to disseminate information in a network. Unlike actors with a low value of closeness centrality, the far distance between the actors with other actors would hamper to the spread of information from informants. Here is an example of regulation, showing the closeness of population with other actors in the implementation of e-KTP:

Presidential Decree No. 126 of 2012 concerning the Third Amendment on the Presidential Decree No. 26 of 2009 concerning the implementation of NIK-based KTP Nationwide.

Article 10 B paragraph (2):

Government Institutions, Regional Governments, Banking and Private Institutions are obliged to serve the public on the basis of e-KTP by not considering the place of issuance of the eKTP.

\section{(3) Eigenvector Centrality}

By using Eigenvector Centrality Measurement, Table 9 and Figure 11 are obtained. When traced by reference from the explanation of previous analysis, population centrality is more dominant at in-degree, most widely accessed by other actors. This explanation confirms that the population is only the object of policy product. In other assessments such as betweenness centrality, closeness centrality and out-degree, the population value is also quite dominant. It can be seen from the many relationships/links owned by the population with other actors, since it has the highest value of eigenvector centrality, as can be seen in the visualization.

The result of data processing with Social Network Analysis shows that the population became the most central actor in the network. Following the population, the Executing Institutions, Dukcapil, Officers, the Head of administrative villages, Resident Aliens, and Minister of Home Affairs respectively have the next highest eigenvector centrality value. The six actors have quite a lot of relations with other actors in the network of e-KTP implementation. The greater number of relationships makes the six actors have higher eigenvector centrality value than any other actors. The seven actors indeed have a lot of relations with other actors both as node 01 and node 02 in the network of e-KTP implementation. The seven actors can be regarded as the key actors in the network due to their high centrality compared with other actors.

This study shows how important the position and role of the population to be the mediator between other actors in the regulation of national e-KTP--as seen from its highest value of betweenness centrality.

The stakeholders (actors) who has not been set explicitly or inconsistent (corresponding to their normative role) in a number of existing regulations/Laws are: (1) Executing Institutions, (2) Minister of Home Affairs and (3) Actors 
involved in the birth certificate (parents, doctors, midwives, paramedics, birth attendants, family, chieftain/customs, police, power, religious courts, state courts and civil registry).

The executing institutions have the secondhighest in-degree value--after population, from the values of other actors. This means the executing institutions are the most frequently accessed actor by other actors in the policy of the National e-KTP. In other words, the executing institutions in relation to other actors often play a role as an object in the policy of the National e-KTP. In the context of Civic System, the lack of clarity of executing institutions' role as an object is too large, potentially confusing the public.

The Minister of Home Affairs has the highest out-degree value. This means, the Minister of Home Affairs is the actor who played an important role (subject), capable to access other actors. The out- degree value of the Minister, on the other hand, shows the too-centralistic position and role of the Minister of Home Affairs in the national e-KTP policies and regulations, both in provinces in Indonesia. in the decentralization era, this role should be given to the lowest level of regional heads. Unfortunately the district head, village heads, sub-department, administrative village heads, mayors/regents and the governor is actually below the Minister of Home Affairs. This causes the e-KTP service to be slow and centralized.

To answer the second question, what kind of policy improvement should be done by the Government of Indonesia in addressing the challenges of demographic bonus, and in order to refine the guidelines for the central and regional governments to carry out the KTP-el service regularly, the Ministry of Internal Affairs is preparing a legal basis as follows: First, revising the Government Regulation No. 37 Year 2007 on Implementation of Law No. 23 of 2006, on the Population Administration, namely: (1) Changes in government regulation is at this point already in the process of filing the signing of the President; (2) change of loading the budget from the Regional Budget to the State Budget for the provision of data communication networks and
KTP-el forms that have been widely questioned by the regional governments to the Ministry of Internal Affairs.

Second, revising the Presidential Decree No. 26 of 2009 as amended by Presidential Regulation No. 35 Year 2010 and Presidential Regulation Number 67 of 2011. The fundamental alteration in the revision of the Presidential Decree is in the deadline for the enactment of a non electronic identity card from December 31 to October 31, 2013.

Meanwhile, in order to consolidate the nationwide data cleansing, the corrective measures are taken as follows ${ }^{2}$ : First, fixing the national Population Database, derived from the daily services of Population and Civil Registry that uses SIAK throughout the districts/cities through the Office of Population and Civil Registration. The results of these services are further consolidated and integrated with the recording results of KTP- el nationally to be made as valid and updated data, free from the tendency on data duplication and anomalies.

Second, synchronizing the two data sources already available (SIAK and KTP-el data), since both have different characteristics, yet complementary to each other. SIAK records the entire demographic data without biometrics, while the KTP-el records KTP-compulsory residents with biometrics.

Third, the demographic data consolidation and cleansing refers to Circular Letter of the Minister of Internal Affairs Number: 470/735/SJ, dated February 13, 2013, regarding the Presentation and Use of Demographic Data, addressed to the Governors and Regents/Mayors throughout Indonesia. The consolidation and cleanup efforts of demographic data (in the center, province, and district/city) are conducted inter alia: (1) the Office of Population and Civil Registration provides daily services for population and civil registry services including e-KTP recording; (2) The Ministry of Internal Affairs, the provincial and district/municipal govern-

\footnotetext{
${ }^{2}$ Based on the study of KTP-el by the research team of University of Dr. Moestopo Beragama; based on the interviews with the Director of Population Data Utilization, Directorate General of Population and Civil Registration, the Ministry of Internal Affairs
} 
ments jointly publish demographic data periodically per semester (first half of June 30, and the second half December 31) in order to avoid differences in demographic data. (3) The provincial and/or district/municipal governments may request the Ministry of Internal Affairs to issue Population Data specifically beyond the regular publishing agenda per semester.

Fourth, after the Population Data from districts/cities are consolidated and cleared by the Ministry of Internal Affairs, it will be found out the amount of duplicate data (recorded more than once), so it can be repaired.

Based on the above explanation, in order to answer the challenges of the demographic bonus in terms of nationwide, valid, and updated demographic data presentation through the policy strategy of integrated demographic data acceleration through KTP-el, the results of this study recommend to formulate administrative sanctions in the form of financial penalties for residents who do not report the Occurrence of Residence Moving in the area of the Unitary States of the Republic of Indonesia to the Office of Population and Civil Registration at the original as well as destination district/city, with the consideration that: (1) the residents who do not report their moving cause the invalidity of the demographic data, either in district-/city- as well as a nation-wide scale; (2) Population Administration became disorderly; and (3) Administrative sanctions such as fines of money can give deterrent effect to residents who commit violations.

\section{CONCLUSION}

The integration of population data is truly urgent to answer the challenges of demographic bonus in 2020-2030. This shall, of course, hamper the performance of the Government since priorities are often not achieved simply because of differences in the data. With the integration of the national population policy, public will gain easier and more sustainable access to public services. National identity shall also provide validation, proof of authenticity as a resident.
In addition, the betweenness centrality result indicates that in fact the ownership of e-KTP turns to be lack of connectivity with the birth certificate policy, whereas birth certificate is the basis of the right to identity of every citizen. A birth certificate is an absolute requirement for a child to go to school, make a passport, and claim other rights to identity. Seen from the table of betweennes anomaly, the regulation of e-KTP is not in line with the regulation of identity rights. Parents, doctors, midwives, paramedics, birth attendants, family, chieftain/customs, police, power, religious courts, state courts and civil registry are in fact actors with the least or small capacity to facilitate interaction between nodes so that they can be interconnected.

The result of analysis recommends further studies, focusing on the regulation harmonization to fill in the administration of stakeholders (actors) by reviewing the policy of population identity (in the form of KTP-el) in Indonesia, so that Indonesia has an accurate and integrated population database, to answer the challenges of demographic bonus in 2020-2030.

The integration of population data is expected to be a door for the end of sectoral ego that still characterizes the attitude of stakeholders both at national, sectoral and local levels. Through good synergy among the stakeholders, the challenges of demographic bonus in 2020-2030 will easily be overcome, including through real synergy in the utilization of integrated population data.

The use of the perspective of Administrative Law on Population makes this study truly rich and meaningful and offers a model recommendation of National Population Administration policy of e-KTP that is currently of concern to the Government of Kabinet Kerja Nawacita.

\section{ACKNOWLEDGEMENT}

I am sincerely grateful to Prof. Dr. Triyuni Soemartono, and the Research Team from the Moestopo (Beragama) University involved in the study of e-KTP funded by the DPD RI. I would also express my gratitude to Radhiatmoko who 
has helped analyzing data, for his invaluable feedback and guidance.

\section{REFERENCES}

Adamic, Lada. (2008). "Introductory social network analysis with Pajek, "University of Michigan, Michigan, 2008.http://ocw. mit.edu/courses/ economics/14-15j-networksfall-2009/ assignments/MIT14_15JF09_pajek.pdf

Al-Khouri, A. M., Bal, J. (2007). Digital Identities and the Promise of the Technology Trio: PKI, Samrt Cards, and Biometrics. Journal of Computer Science 3 (5): 361-367.

Asshiddiqie, Jimly. (2011). Pengantar Ilmu Hukum Tata Negara. Rajawali Pers: Jakarta.

Balan, Feyza. (2015). Testing the Demographic Economic Paradox for Newly Industrialized Countries: A Panel Data Analysis. Economic Insights - Trends and Challenges. Vol.IV (LXVII) No. 2/2015.

Barro, R.J. (2003). Determinants of Economic Growth in Panel of Countries, Annals of Economics and Finance, 4, 231-274.

Birg, H. (2001). Die demographische Zeitenwende, Der Bevölkerungsrückgang in Deutschland und Europa, p. 35 ff, 2001.

Bloom, David E., and David Canning (2011), Demographics and Development Policy, PGDA Working Paper No. 66, January. http://www.hsph.harvard.edu/pgda/working.h tm. Diakses pada 7 November 2015.

Brander, J.A., Dowrick, S. (1994). The Role of Fertility and Population in Economic Growth, Journal of Population Economics, 7:1-25.

Castro, Daniel. 2011. Explaining International Leadership: Electronic Identification System. The Information Technology and Innovation Foundation.

Cătăneţ, D. N., Cătăneţ, A. (2008), Facts about Determinants of Economic Growth, The Annals of the University of Oradea. Economic Sciences, Vol. - Economy and Business Administration, 67-70.

Creswell, J.W. Plano Clark, V.Gutmann. M., \& Hatson, W. (2003). Advanced mixhed methods designs. In A. Tashakkori \& C. Teddlie (Ed.), Handbook of Mixed Method Research in the Social and Behavioral
Sciences (pp. 209-240). Thousand Oaks, CA:Sage

Creswell, John W. (2013). Research Design: Qualitative, Quantitative, and Mixed Methods. Fourth Edition. Sage Publication.

Dasgupta, Partha. (1995). "The Population Problem: Theory and Evidence". Journal of Economic Literature 33 (4): 1879-902.

de la Croix, David, and Matthias Doepke. (2003). "Inequality and Growth: Why Differential Fertility Matters." American Economic Review, 93(4): 1091-1113.

Denzin, Norman. K, and Lincoln, Yvonna, S. (2011). The SAGE Handbook of Qualitative Research. SAGE Publications, Inc.

Doepke, Matthias. (2004). Accounting for Fertility Decline During the Transition to Growth. Journal of Economic Growth, 9(3): 347-383.

Fitriati, Rachma. (2014). "Membangun Model Kebijakan Nasional Keamanan Siber dalam Sistem Pertahanan Negara, dengan Pendekatan Soft Systems Methodology dan Social Network Analysis". Jakarta: Universitas Pertahanan ISBN 978-602-17915-6-1

Galor, Oded. (2005). From Stagnation to Growth: Uni_ed Growth Theory. In Handbook of Economic Growth, Vol IA, ed. Philippe Aghion and Steven N. Durlauf, 171\{293. Amsterdam, The Netherlands: Elsevier North-Holland. (2008). "The New Palgrave Dictionary of Economics". p. 109.

Galor, Oded., and David N. Weil. (1996). The Gender Gap, Fertility, and Growth. The American Economic Review, Vol. 86, No. 3, 374-387.

(1999). From Malthusian Stagnation to Modern Growth. American Economic Review, 89(2): 150-154.

(2000). "Population, Technology, and Growth: From Malthusian Stagnation to the Demographic Transition and Beyond." American Economic Review, 90(4): 806-828.

Guba, E. G., \& Lincoln, Y. S. (1994). Competing paradigms in qualitative research. In N. K. Denzin \& Y. S. Lincoln (Eds.), Handbook of qualitative research (pp. 105-117). Thousand Oaks, CA: Sage. 
Hanneman, Robert A. and Mark Riddle. (2005). Introduction to Social Network Methods. Riverside, CA: University of California, Riverside (published in digital format http://faculty. ucr.edu/ hanneman/ )

Hay, Iain. (2010). Qualitative Research Methods in Human Geography 3rd Edition. Oxford University Press

Johnson, David Gale; Lee, Ronald Demos, eds. (1987). Population Growth and Economic Development: Issues and Evidence. University of Wisconsin Press.

Kelley, Allen C.; Schmidt, Robert M. (2008). "The New Palgrave Dictionary of Economics". p. 655.

Kremer, Michael. (1993). "Population Growth and Technological Change: One Million B.C. to 1990". The Quarterly Journal of Economics 108 (3): 681-716

Lee, Ronald D. (2008). "The New Palgrave Dictionary of Economics". p. 512.

Li, H, and Zhang, J. (2007). Do High Birth Rates Hamper Economic Growth, The Review of Economics and Statistics, 89(1): 110-117.

Luci, A., and Thevenon, O. (2010). Does Economic Development Drive the Fertility Rebound in OECD Countries, HAL archievesouvertes.fr

Malthus, Thomas Robert. (2000). An Essay on the Principle of Population. Library of Economics" (description), Liberty Fund, Inc., EconLib.org webpage: EconLib-MalPop.

Meleng, Samad; Sangun, Enisar, et al. (2015). Implementasi Integrasi Administrasi Kependudukan Nasional. A Result of Research at the Center of the Regional Study, The House of Regional Representatives of the Republic of Indonesia.

Mishra, V., Nielsen, I., Russell, S. (2010). On the Relationship between Female Labour Force Participation and Fertility in G7 countries: Evidence from Panel Cointegration and Granger Causality, Empirical Economics, Springer, vol. 38(2): 361-372
Müller-Prothmann, T. (2006): Use and Methods of Social Network Analysis in Knowledge Management. In E. Coakes \& S. Clarke (eds.): Encyclopedia of Communities of Practice in Information and Knowledge Management, pp. 565-574. Hershey/PA et al.

Can, Fazli; Özyer, Tansel; and Polat, Faruk. (Ed). (2014). State of The Art Applications of Social Network Analysis. Springer International Publishing Switzerland. ISBN 978-3319-05912-9. DOI 10.1007/978-3-31905912-9

Scott, John. (1991). Social Network Analysis: a Handbook. London: Sage. ISBN: 0-80398480-4.

Soemartono, Triyuni. (2013). "The Dynamic of e-KTP Evaluation Program in DKI Jakarta”. Bisnis \& Birokrasi Journal, Vol. 20, No 2.

Teitelbaum, Michael S. (1975). "Relevance of Demographic Transition Theory for Developing Countries", in Science, New Series, Volume 188, Issue 4187 (May 2, 1975), 420-425.

Ulrike, Gretzel. (2001). Social Network Analysis: Introduction and Resources. http:// lrs.ed.uiuc.edu/tse-portal/analysis/socialnetwork-analysis/ Accessed on 12-May2014

Valdis, Krebs. (2014). Social Network Analysis, A Brief Introduction. http://www. orgnet.com/sna.html. Accessed on 12-May2014.

van Praag, Bernard M. S. (1988). "The notion of population economics". Journal of Population Economics 1 (1): 5-16.

Wellman, Barry Berkowitz, S.D. (ed). (1988). Structural Analysis in the Social Sciences. Social Structures: A Network Approach. Cambridge University Press. ISBN 0521 244412.

Wasseerman, Stanley and Katherine Faust. (1994). Social Network Analysis: Methods and Applications (Structural Analysis in the Social Sciences). Cambridge Univresity Press. ISBN 9780521387071. 


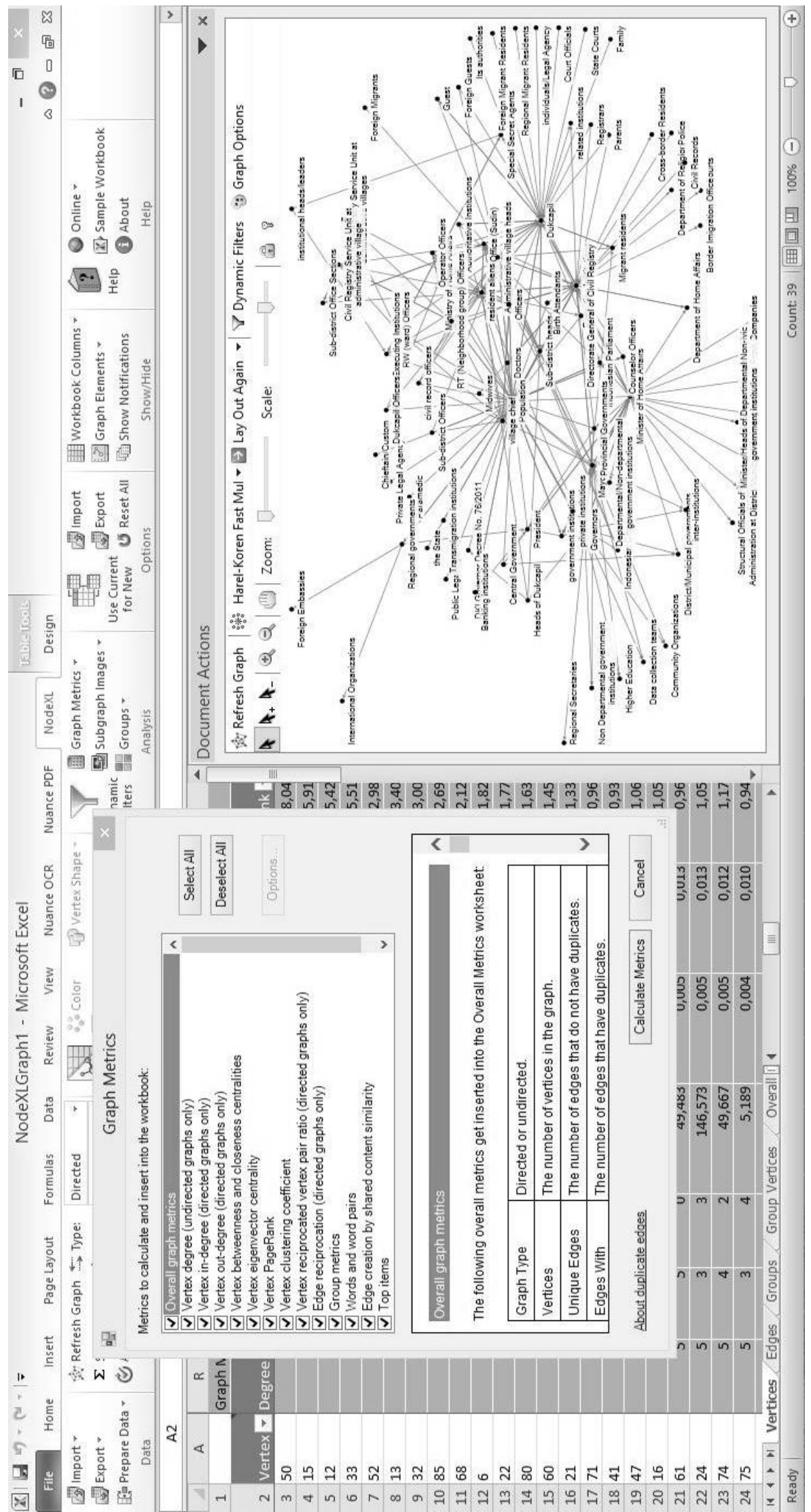

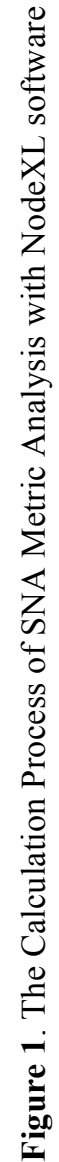




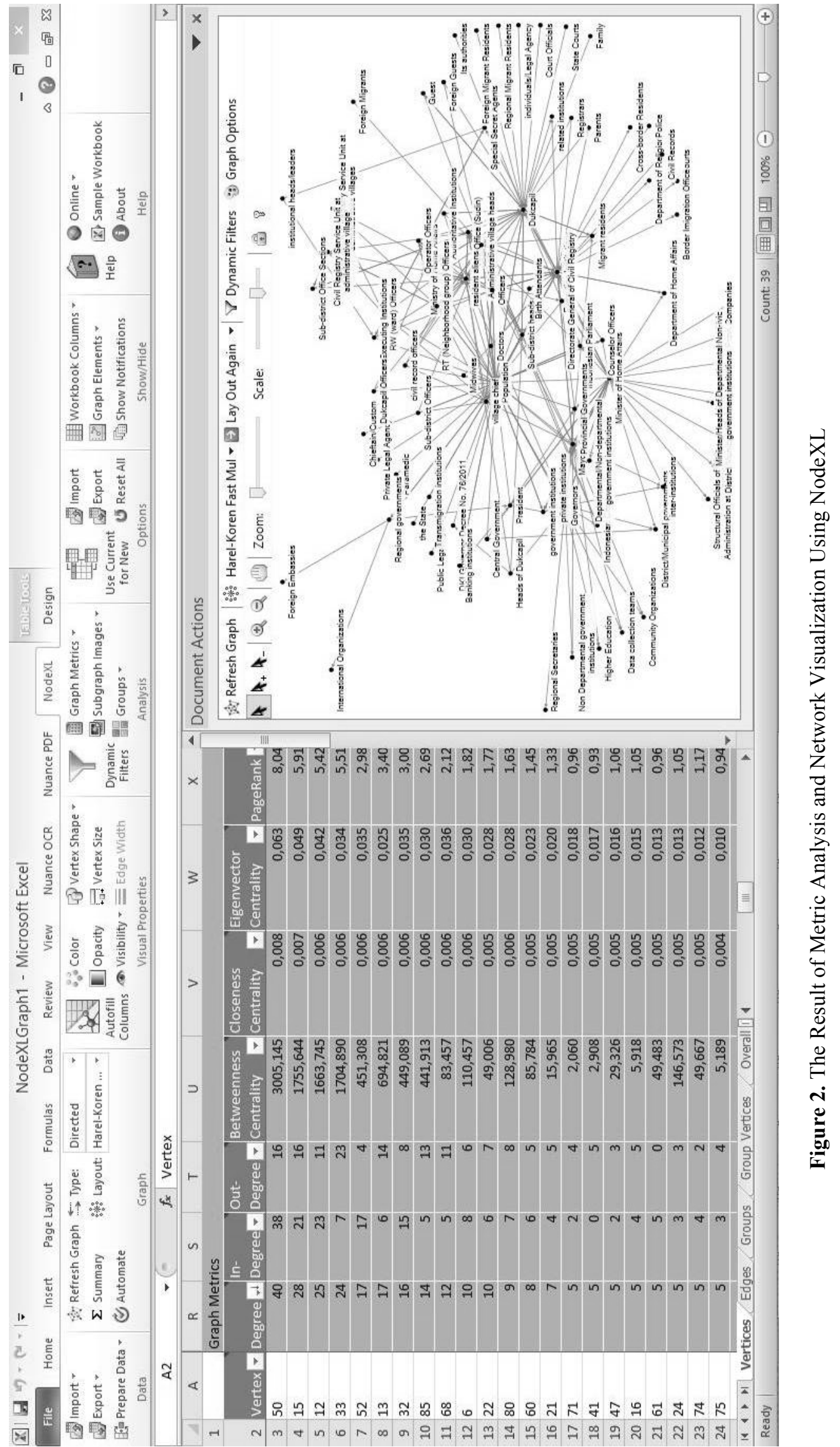


Figure 6. The Visualization of the Entire Actors in the Regulation of e-KTP Implementation

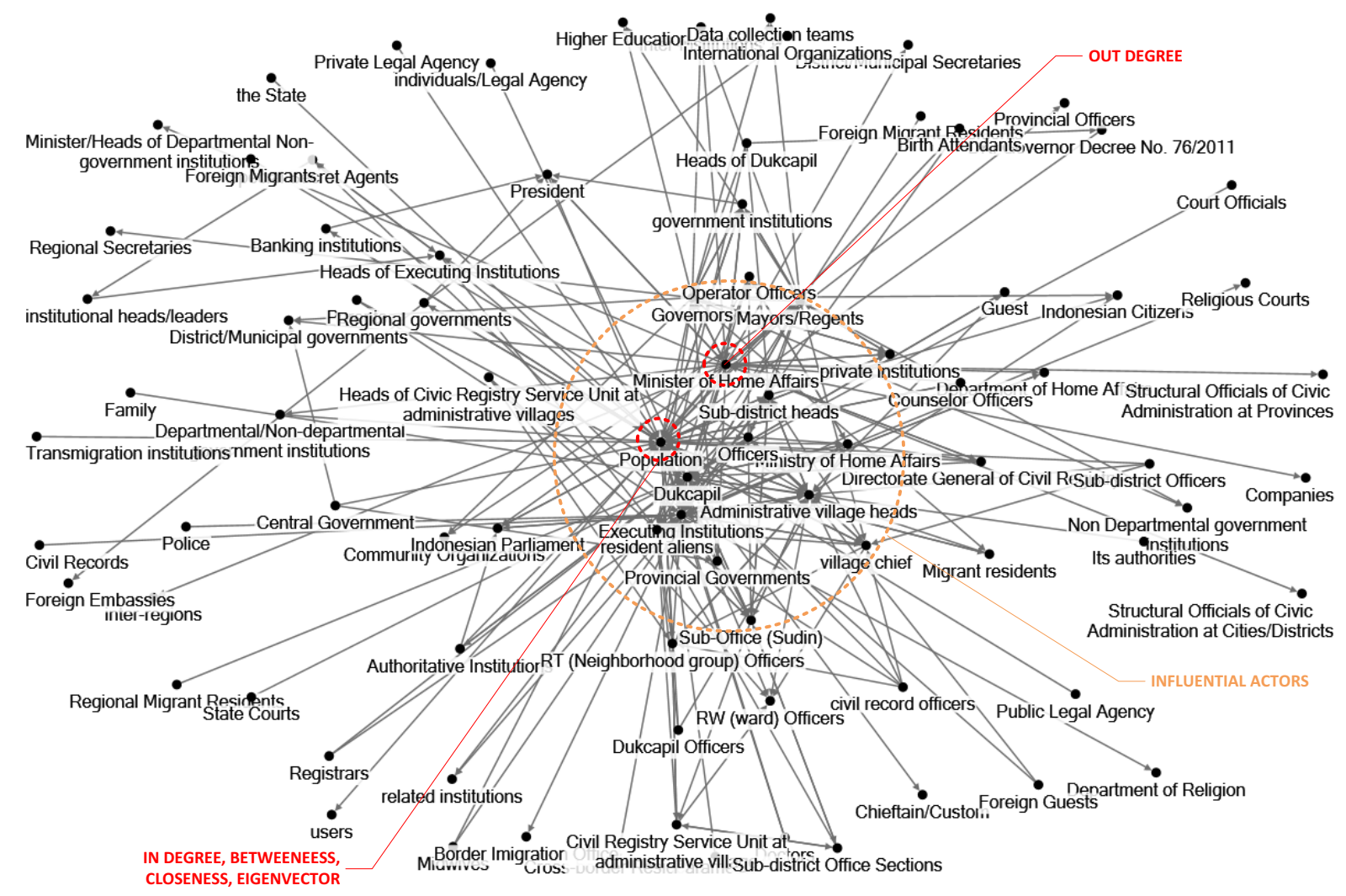

Figure 7. The In-Degree Visualization of e-KTP Regulation

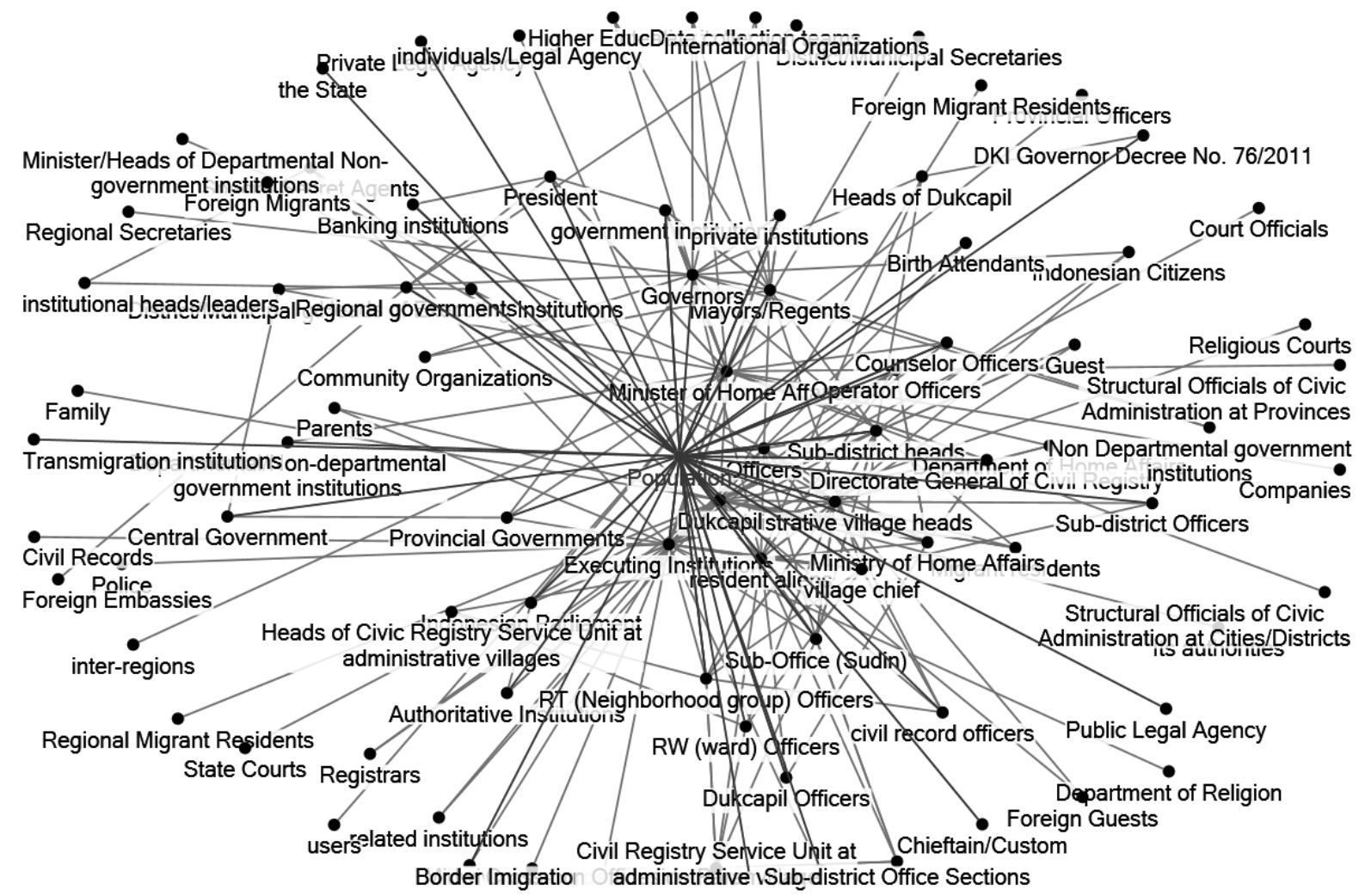


Figure 8. The Out-Degree Visualization of E-KTP Regulation

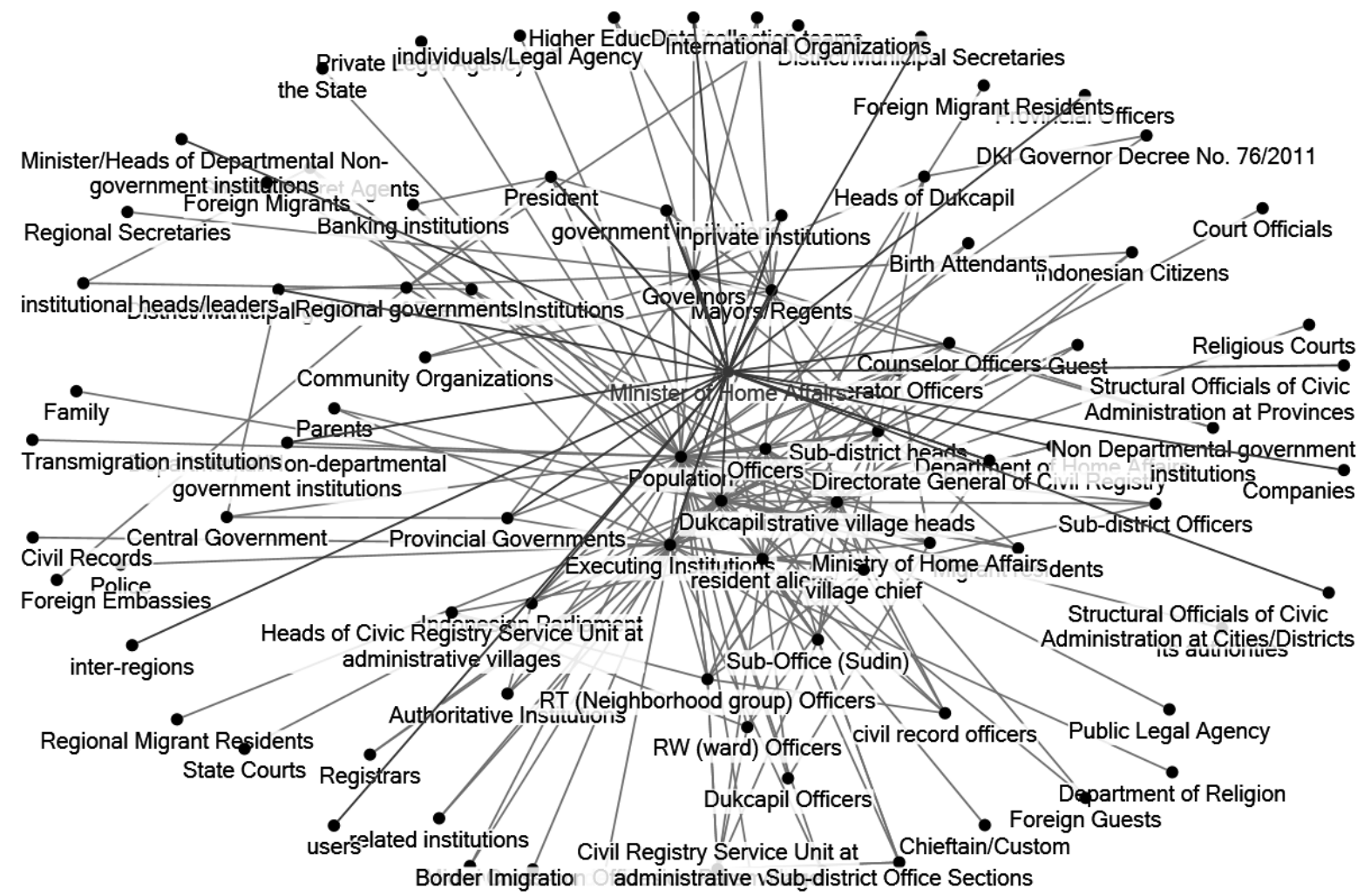

Figure 9. The Betweenness Centrality Visualization of E-KTP Regulation

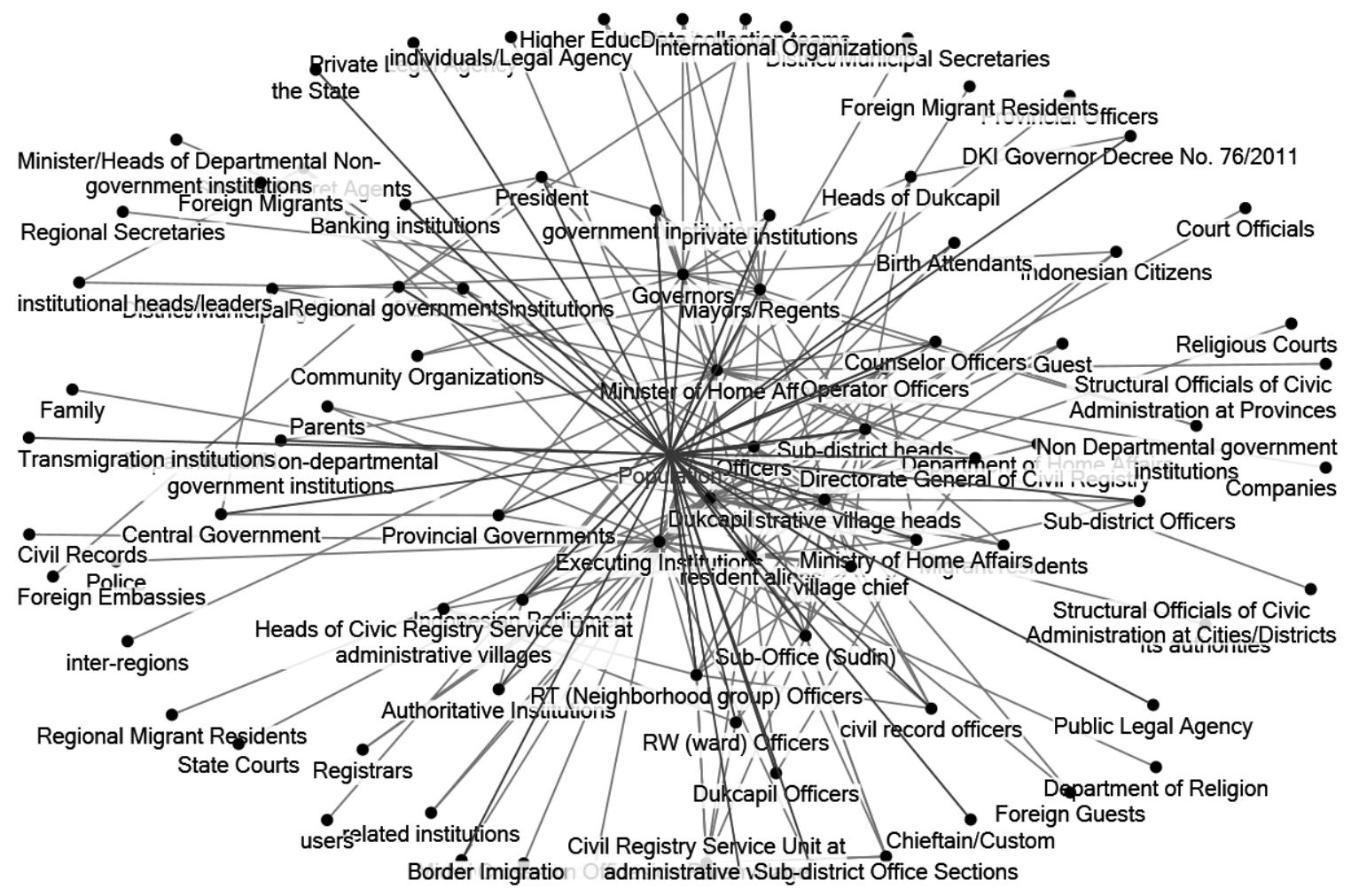


Figure 10. The Closeness Centrality Visualization of e-KTP Implementation

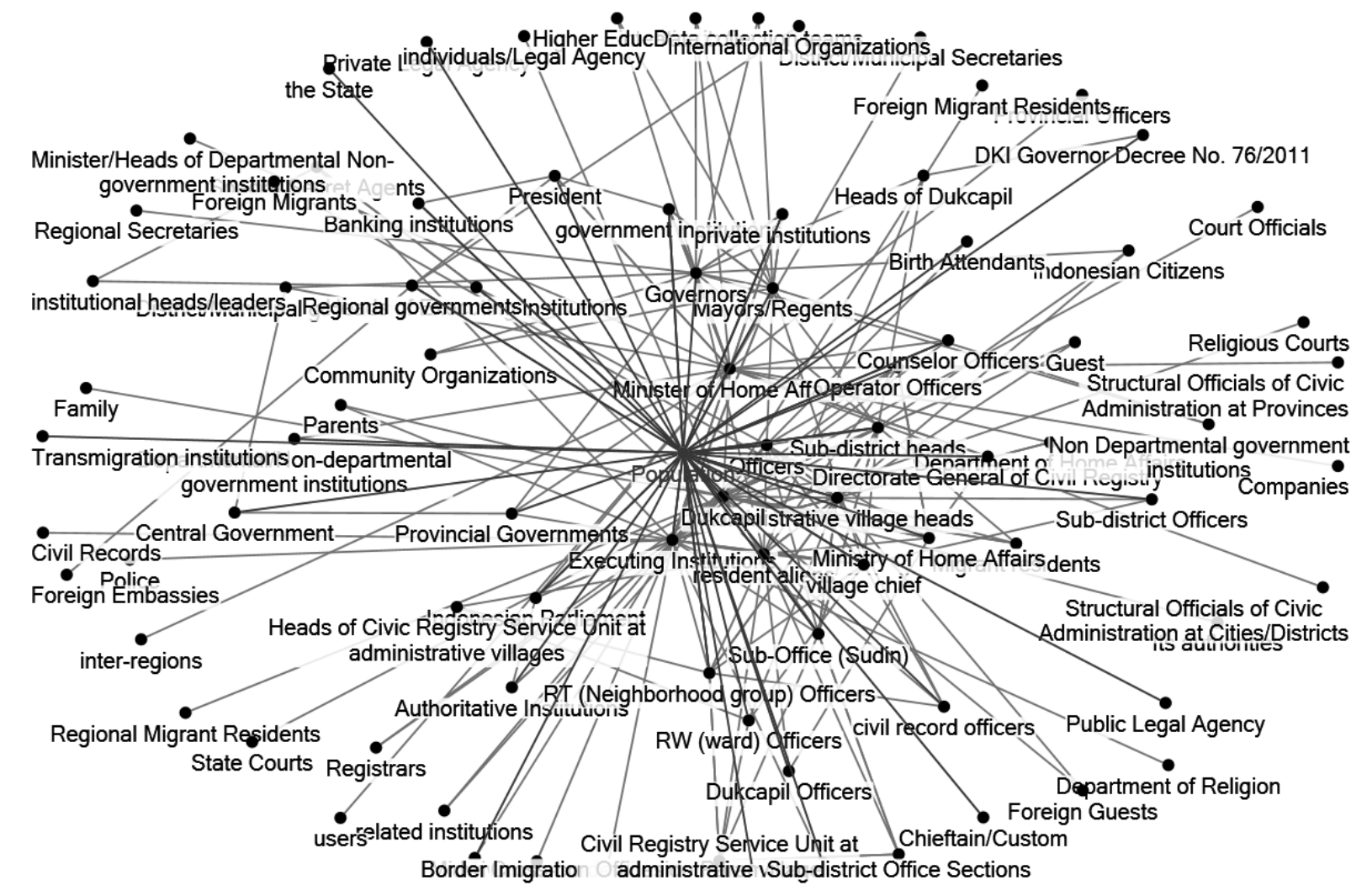

Figure 11. The Eigenvector Centrality Visualization of e-KTP Implementation

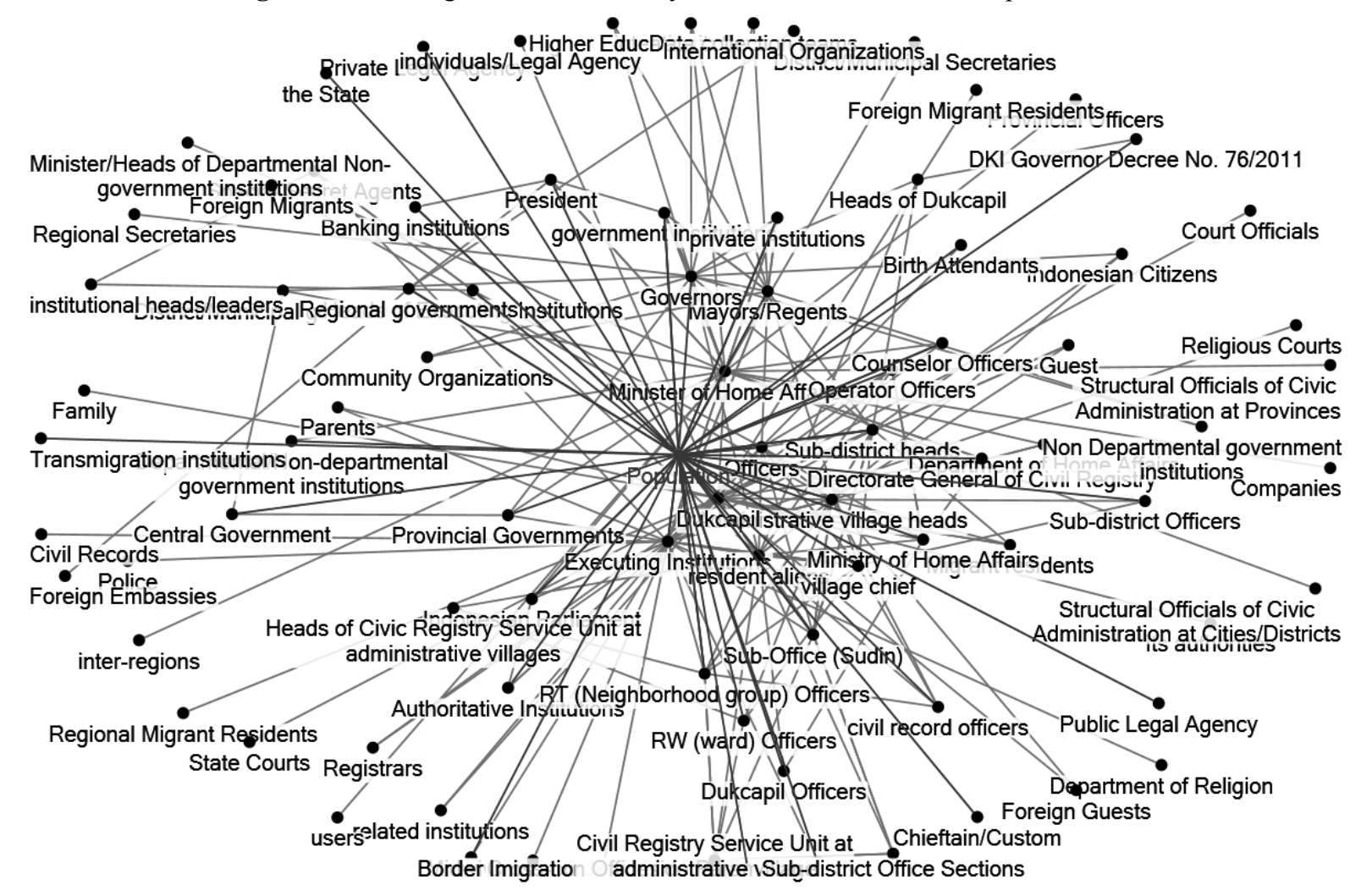


Table 2. The Mapping of Actors in Population Administration Law by Using SNA

\begin{tabular}{|c|c|c|c|c|c|}
\hline 1 & Inter-regions & 31 & Banking Institutions & 61 & RW (Ward) Officers \\
\hline 2 & Inter-institutions & 32 & Head of administrative villages & 62 & Birth Attendants \\
\hline 3 & Private Legal Agency & 33 & Minister of Home Affairs & 63 & $\begin{array}{l}\text { DKI Governor Regulation No. } \\
76 / 2011\end{array}$ \\
\hline 4 & Public Legal Agency & 34 & $\begin{array}{l}\text { Minister/Heads of Departmental } \\
\text { Non-government Institutions }\end{array}$ & 64 & Higher Education \\
\hline 5 & Midwives & 35 & the State & 65 & Companies \\
\hline 6 & Head of Sub-districts & 36 & Parents & 66 & Foreign Embassies \\
\hline 7 & Department of Religion & 37 & International Organizations & 67 & Indonesian Parliament \\
\hline 8 & $\begin{array}{l}\text { Department/Non-departmental } \\
\text { Government Institutions }\end{array}$ & 38 & Community Organizations & 68 & Officers \\
\hline 9 & Department of Home Affairs & 39 & Paramedic & 69 & Dukcapil officers \\
\hline 10 & $\begin{array}{l}\text { Directorate General of Civil } \\
\text { Registry }\end{array}$ & 40 & Counselor Officials & 70 & Sub-district officers \\
\hline 11 & Doctors & 41 & Civil Record Officers & 71 & Operator officers \\
\hline 12 & Dukcapil & 42 & Courts Officers & 72 & Provincial officers \\
\hline 13 & Governors & 43 & $\begin{array}{l}\text { Structural Officials of Civil } \\
\text { Administration at Cities/Districts }\end{array}$ & 73 & Special Secret Agents \\
\hline 14 & Authoritative Institutions & 44 & Central Government & 74 & President \\
\hline 15 & Executing Institutions & 45 & Regional Governments & 75 & $\begin{array}{l}\text { Civic Registry Service Unit at } \\
\text { administrative villages }\end{array}$ \\
\hline 16 & Governmental Institutions & 46 & Districts/Municipal Governments & 76 & Regional Secretaries \\
\hline 17 & Related institutions & 47 & provincial Governments & 77 & Districts/Municipals Secretraries \\
\hline 18 & Transmigration institutions & 48 & Civil Records & 78 & Sub-district Office Sections \\
\hline 19 & Border Imigration Office & 49 & Foreign Migrants & 79 & Individuals/legal Agency \\
\hline 20 & Family & 50 & Population & 80 & Sub-Office (Sudin) \\
\hline 21 & Ministry of Home Affairs & 51 & Cross-border residents & 81 & Private Institutions \\
\hline 22 & Village heads & 52 & Foreign residents & 82 & Guests \\
\hline 23 & Heads of Dukcapil & 53 & Migrant residents & 83 & Foreign Guests \\
\hline 24 & Heads of executing institutions & 54 & Reginal Migrant Residents & 84 & Data Collection Team \\
\hline 25 & $\begin{array}{l}\text { Heads of Civic Registry Service } \\
\text { Unit at administrative villages }\end{array}$ & 55 & Foreign Migrant Residents & 85 & Mayors/Regents \\
\hline 26 & Chieftain/Custom & 56 & Indonesian Citizens & 86 & Registrars \\
\hline 27 & Institutional Heads/Leaders & 57 & Religious courts & 87 & $\begin{array}{l}\text { Structural Officials of Civic } \\
\text { Administration at Provinces }\end{array}$ \\
\hline 28 & Police & 58 & State courts & & \\
\hline 29 & its authorities & 59 & Users & & \\
\hline 30 & $\begin{array}{l}\text { Non-departmental Government } \\
\text { Institutions }\end{array}$ & 60 & RT (neighborhood group) officers & & \\
\hline
\end{tabular}


Table 3. The Mapping of Relations in Population Administration Law by Using SNA

\begin{tabular}{|c|c|c|c|c|c|}
\hline & cooperate & 26 & annul & 51 & manage \\
\hline 2 & coordinate & 27 & record & 52 & return \\
\hline 3 & execute decision & 28 & give record & 53 & learn \\
\hline 4 & go through & 29 & print & 54 & use \\
\hline 5 & report & 30 & register & 55 & identify \\
\hline 6 & give report & 31 & give registry & 56 & inform \\
\hline 7 & serve & 32 & get & 57 & give information \\
\hline 8 & protect & 33 & collect data & 58 & send \\
\hline 9 & call for & 34 & pay a visit & 59 & deliver \\
\hline 10 & help & 35 & distribute & 60 & consolidate \\
\hline 11 & form & 36 & posit & 61 & change \\
\hline 12 & stop & 37 & explain & 62 & arrange \\
\hline 13 & give access & 38 & issue & 63 & propose \\
\hline 14 & give socialization & 39 & receive & 64 & asses \\
\hline 15 & give & 40 & receive data & 65 & schedule \\
\hline 16 & tell & 41 & receive information & 66 & guarantee \\
\hline 17 & supervise & 42 & receive reports & 67 & return \\
\hline 18 & ask & 43 & transmit & 68 & appoint \\
\hline 19 & ask for permission & 44 & determine & 69 & show \\
\hline 20 & ask for report & 45 & propose & 70 & deliver \\
\hline 21 & personalize & 46 & take & 71 & select \\
\hline 22 & process & 47 & appoint & 72 & submit \\
\hline & decide & 48 & direct & 73 & keep \\
\hline & verify & 49 & administer & 74 & record \\
\hline 25 & sign & 50 & supervise & 75 & as \\
\hline
\end{tabular}


Table 4. The Visualization of the Entire Actors in the Regulation of e-KTP Implementation

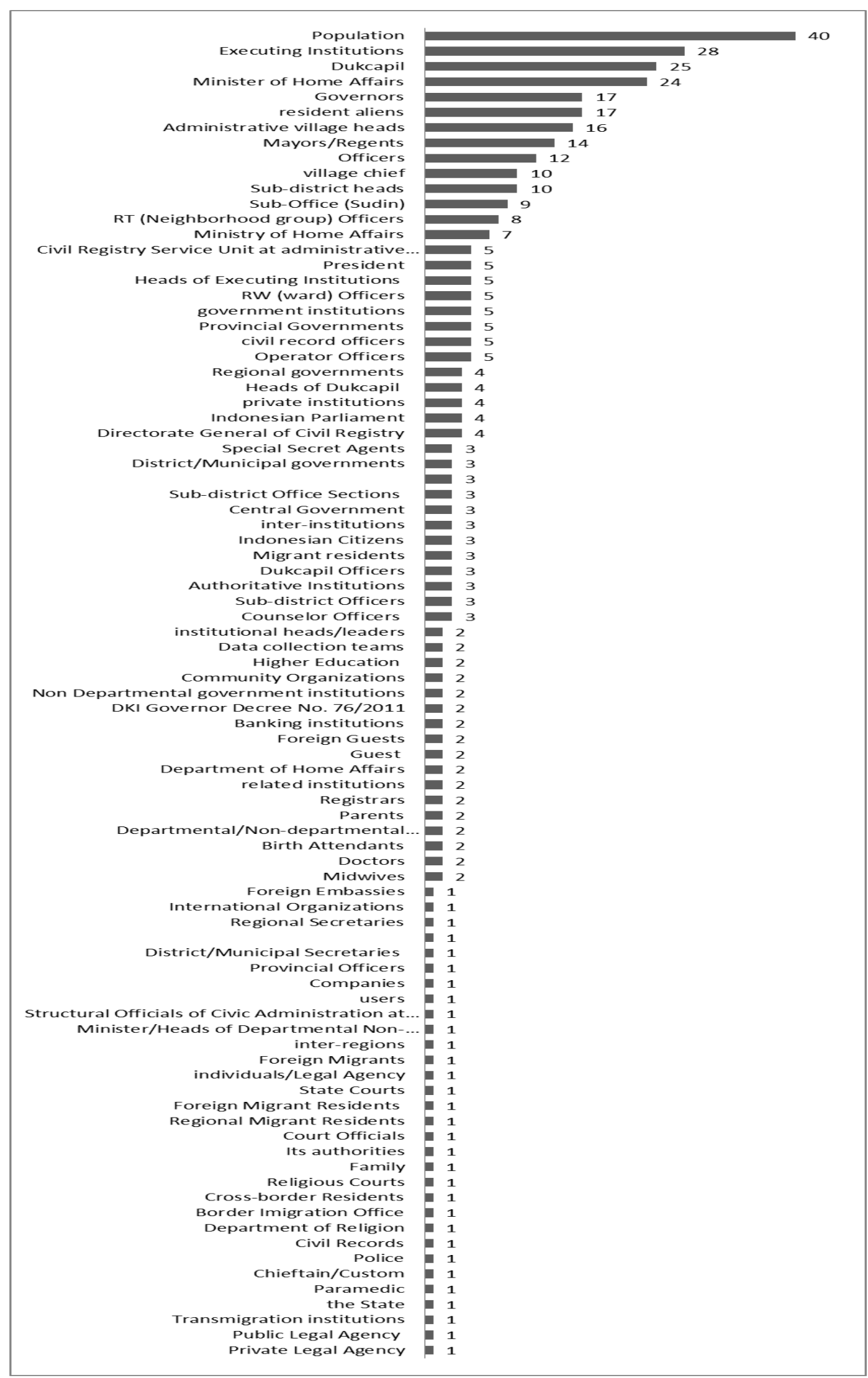


Table 5. The In-Degree Visualization of e-KTP Regulation

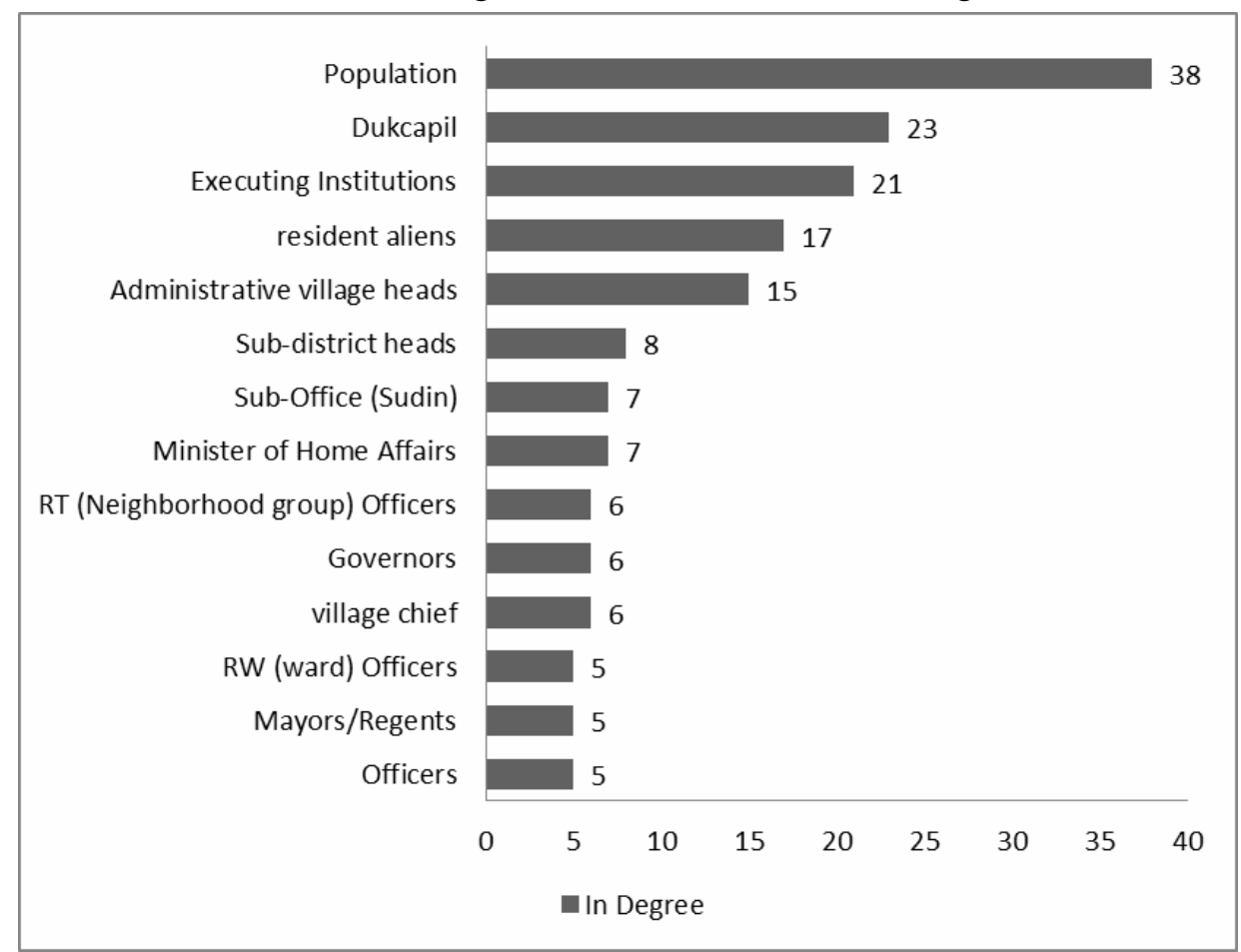

Table 6. The Out-Degree Visualization of E-KTP Regulation

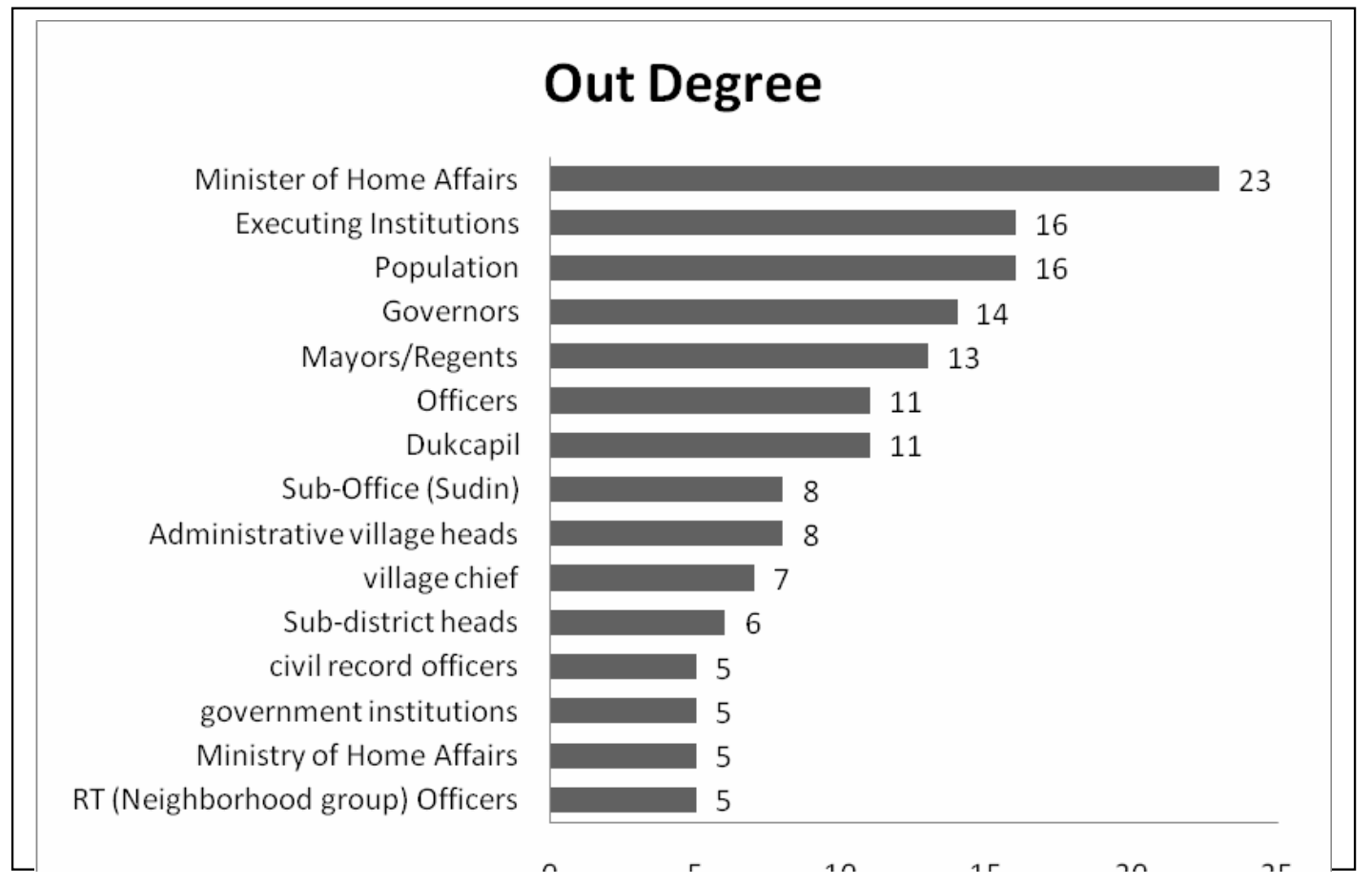


Table 7. The Betweenness Centrality Visualization of E-KTP Regulation

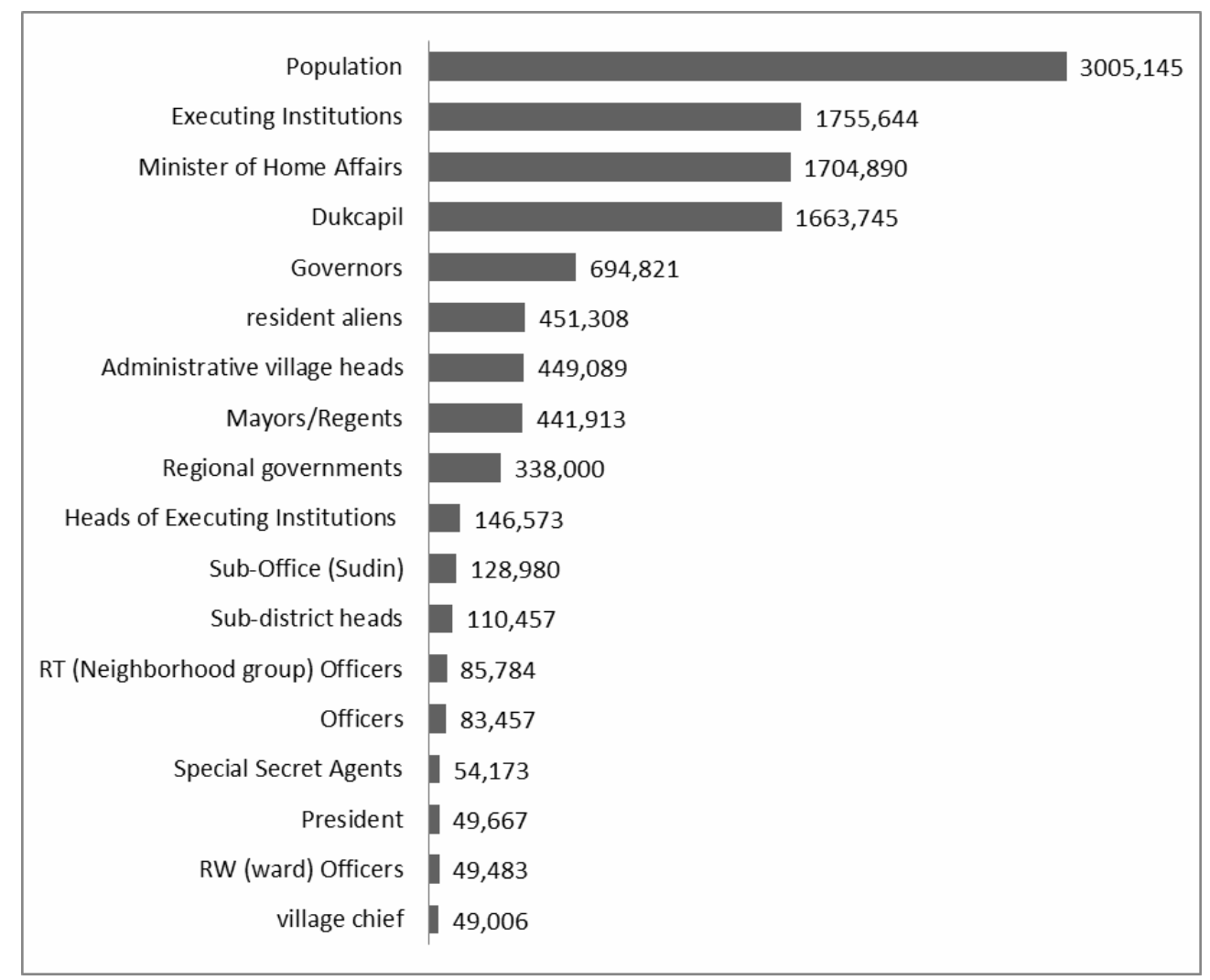

Table 8. The Closeness Centrality Visualization of e-KTP Implementation

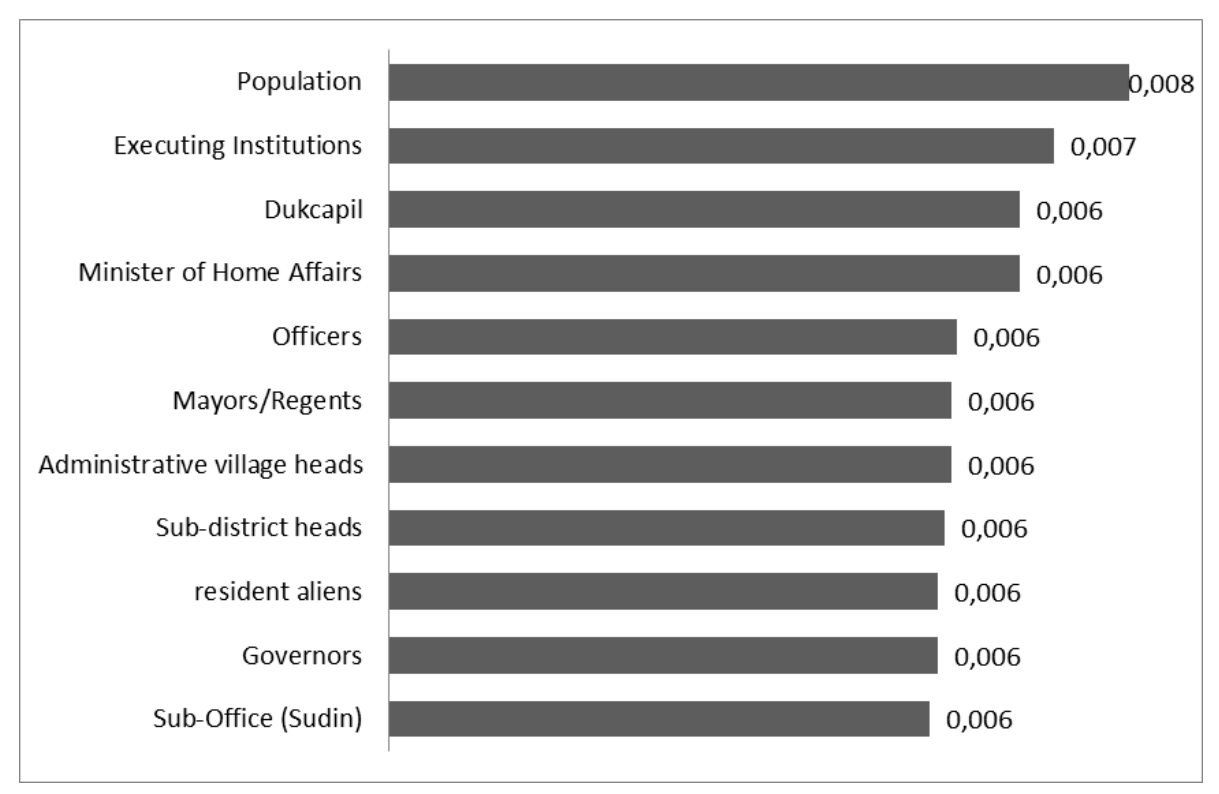


Table 9. The Eigenvector Centrality Visualization of e-KTP Implementation

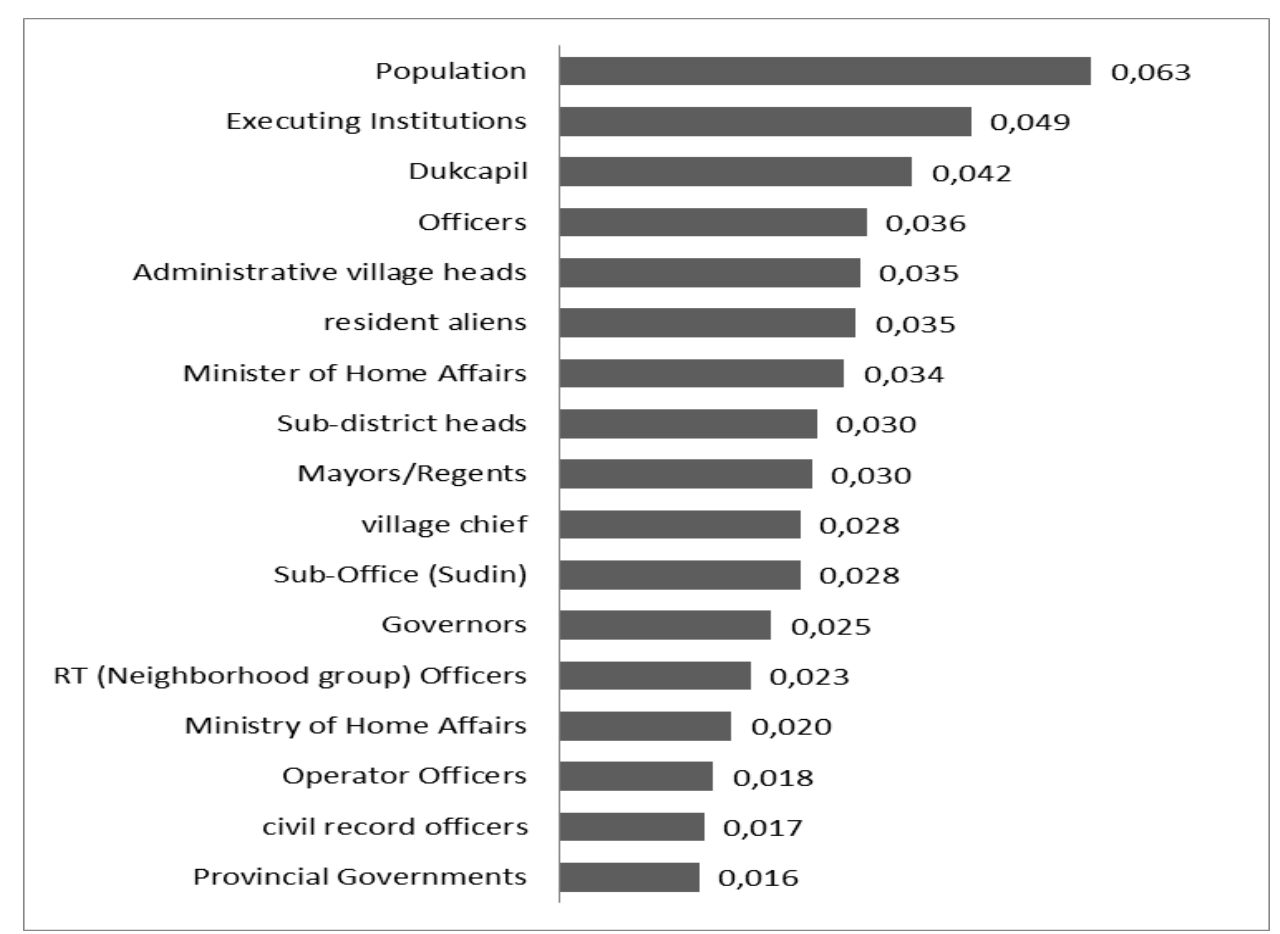

